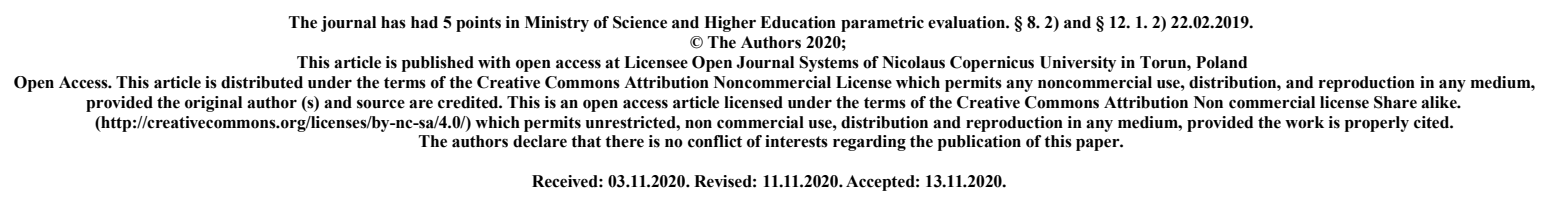

\title{
The influence of wearing masks and gloves due to COVID-19 pandemic on skin problems and skin care in students of Medical University in Lublin
}

\author{
Aleksandra Jaremek ${ }^{1}$, Wiktoria Chodun ${ }^{1}$, Justyna Piechnik ${ }^{1}$, \\ Barbara Nieradko-Iwanicka ${ }^{2}$
}

${ }^{1}$ Students' Scientific Association at the Chair and Department of Hygiene Medical University of Lublin

${ }^{2}$ Chair and Department of Hygiene, Medical University of Lublin Radziwillowska 11 Street, 20-080 Lublin;

Correspondence: Barbara Nieradko-Iwanicka

e-mail barbara.nieradko-iwanicka@umlub.pl

Abstract

Introduction. Our everyday life has changed drastically in these few months. The arrival of the new 2019-nCoV virus in December 2019 and its rapid spread from the city of Wuhan, China, has highlighted the increase in personal protective equipment (PPE).

The aim of the study was to to learn about the influence of wearing masks and gloves due to COVID-19 pandemic on skin problems and skin care in students of Medical University in Lublin.

Material and methods. In October 2020, we conducted a survey with use of a questionnaire.

Results. A total of 59 persons completed the questionnaire. Only one person reported not wearing the mask as recommended. For $54 \%$ of participants, wearing a mask had an impact on the occurrence of skin problems, such as acne. A similar number of respondents answered positively to the question about the influence of masks on their makeup. These people used to wear much less makeup. Most of them only paint the eyes because the material is covering the mouth. More than half of the respondents do not wear gloves, they wash or disinfect hands. In $61 \%$ of respondents, there was no problems with hand skin or nails, such as brittleness, mycosis, discoloration, allergic dermatitis or contact dermatitis. The vast majority cared more about moisturizing the skin of the hands. 
Conclusion. Wearing masks by students of Medical University of Lublin increases skin problems like acne and reduces the amount of makeup applied. Due to wearing gloves students focus more on moisturizing the skin.

Keywords: masks; gloves; COVID-19 pandemic; skin problems; behavior

\section{Introduction}

Our everyday life has changed drastically in these few months. The arrival of the new 2019nCoV virus in December 2019 and its rapid spread from the city of Wuhan, China, has highlighted the increase in personal protective equipment (PPE). The obligation to wear masks in public spaces sparked a lot of debate about their impact on the body. The World Health Organization (WHO) emphasized that wearing them is not always good for our health (1). It is recommended to wash and disinfect hands and wear gloves in order to prevent the spread of infection (2).

The aim of the study was to learn about the influence of wearing masks and gloves due to COVID-19 pandemic on skin problems and skin care in students of Medical University in Lublin.

Matherials and Methods

In October 2020, we conducted a survey with use of the questionnaire consisting of 10 questions to check the impact of the obligation to wear masks and gloves on the skin. The survey was voluntary and anonymous. A total of 59 students of the Medical University of Lublin took part in it. The questions asked were:

- Age

- Gender

- Faculty

- Year of studies

- Does wearing a mask affect your skin problems (like youth acne)?

- Does wearing a mask affect your makeup?

- If it does-how?

I don't wear makeup at all

I wear more make up

I wear less makeup

I only do eye makeup

I'm just applying undercoat

I only use my lipstick

- Does wearing gloves affect your skin and nail problems? (brittleness, mycosis, discoloration?)

- Does wearing gloves affect the care of your hands?

I care more about my hands

I care less about my hands 
I do a manicure more often

I do a manicure less often

I'm not doing a manicure at all

I put a hybrid on my nails

I apply classic nail enamel

Results

A total of 59 persons completed the questionnaire (55 women and 4 men). The average age of the participants was 20-21 years. They were students of the Faculty of Health Sciences, the Faculty of Pharmacy and the Faculty of Medicine.Only one person reported not wearing the mask as recommended. For $54 \%$ of participants, wearing a mask had an impact on the occurrence of skin problems, such as acne (Fig. 1.). A similar number of respondents answered positively to the question about the influence of masks on their makeup (Fig. 2.). Students admitted to wearing less makeup than before the COVID19 pandemic. Most of them only paint the eyes because the material is covering the mouth (Fig. 3.). More than half of the respondents do not wear gloves. They just wash hands as often as possible or disinfect hands with alcohol-based formulas. About $61 \%$ of respondents reported no problems with skin or nails, such as brittleness, mycosis, discoloration (Fig. 4.). The vast majority care more about moisturizing the skin of the hands (Fig. 5.).

Fig. 1. Answers to question No5: Deas wearing a mask affect your skin problems (e.g. acne)?

\section{Does wearing a mask affect your skin problems (e.g.} acne)?

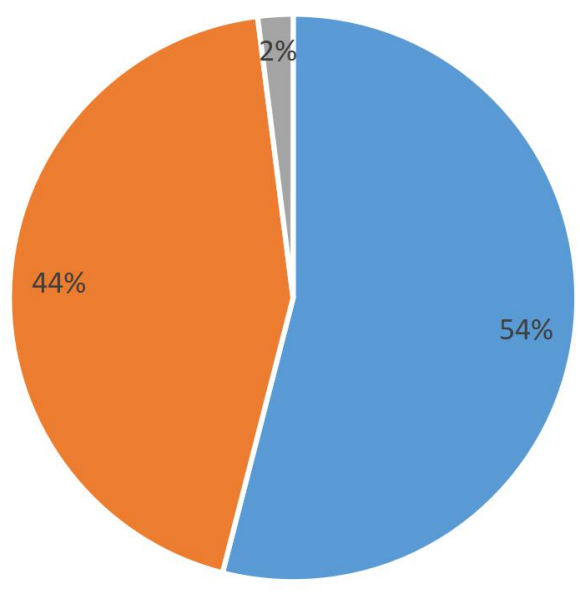

$\square$ Yes $\square$ No $\square$ Lack 
Fig. 2. Answers to question No6: Does wearing a mask affect your makeup?

6. Does wearing a mask affect your makeup?

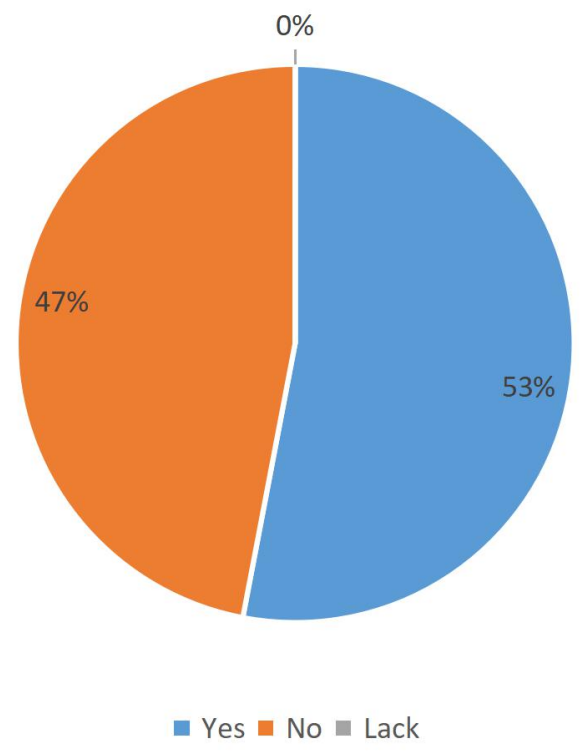

Fig. 3. Answers to question No7: If the answer to question 6 was 'Yes', please select 1 or more answers how wearing the mask affects your makeup.

7. If the answer to question 6 was 'Yes', please select 1 or more answers to how wearing the mask affects your makeup

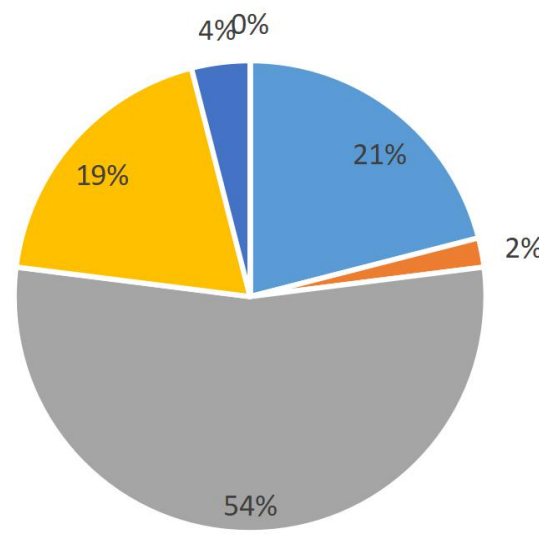

\footnotetext{
- I don't make up

- I only paint my eyes
}

$$
\begin{aligned}
& \text { - I paint more } \quad \text { I paint less } \\
& \text { - I'm just putting on a foundation } \text { " I only paint my lips }
\end{aligned}
$$


Fig. 4. Answers to question No9: Does wearing gloves affect your skin or nail problems(brittleness, mycosis, discoloration)?

9. Does wearing gloves affect your skin or nail problems

(brittleness, mycosis, discoloration)?

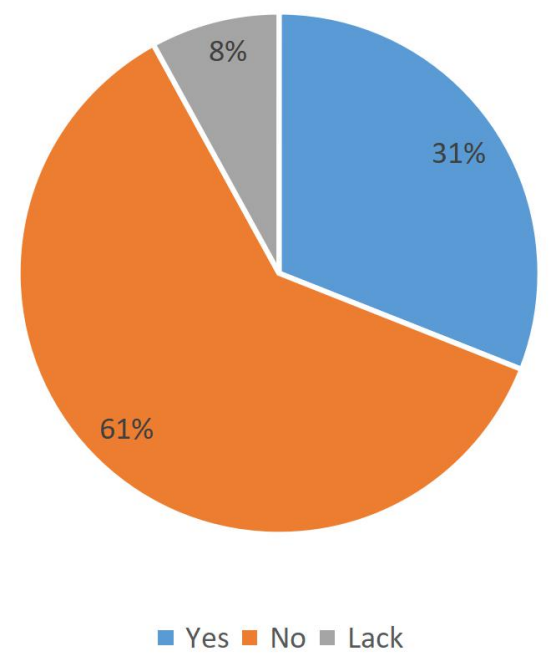

Fig. 5. Answers to question No10: Does wearing gloves as recommended affect the care of your hands?

10. Does wearing gloves as recommended affect the care of your hands?

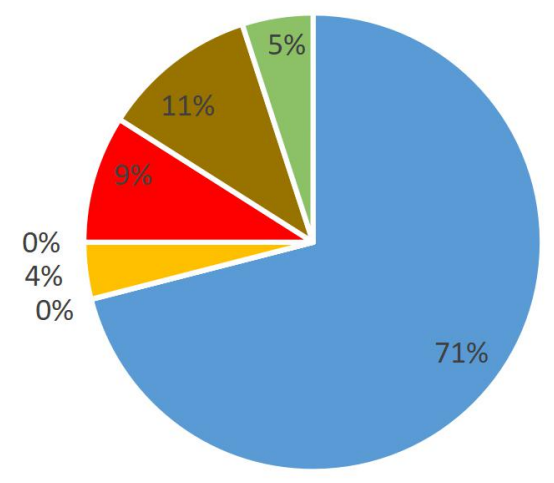

- I care more about moisturizing the skin of my hands a I care less for the skin of my hands

- I do a manicure more often

- I do a manicure less often

- I don't do a manicure at all

- I put on a hybrid

- I apply classic varnish 


\section{Discussion}

According to WHO guidelines, a medical mask should:

- Be changed often enough, especially if it is wet, dirty or damaged;

- Be not touched. It is forbidden to touch the mask with hands, if they have not been previously hygienically washed;

- Be discarded and replaced after patient care as a range of precautions against transmission of pathogens (1).

The harm and risks of wearing masks include the health effects of poor air quality and toxic components of the mask, self-contamination from touching the mask with contaminated hands, general discomfort, damage to the facial skin, dermatitis or worsening acne, and a false sense of security that can reduce compliance with others preventive measures such as hand hygiene (3). These are caused by prolonged sealing, friction and pressure.

The WHO lists many potential risks and harms associated with wearing a mask and gloves $(1,2)$. People wearing masks and gloves must be aware of side effects of their continuous use, which are:

- It is difficult to wear masks in a humid and hot environment;

- Overconfidence in security reduces the perception of other important safety measures, such as washing hands;

- Due to wearing masks people complain about nuisance, as well as facial skin changes, dermatitis and aggravating acne;

- There is a problem with self-contamination from touching the mask without hygienically washing your hands first.

The purpose of PPE is to protect against physical, chemical and biological factors (4). They are made of different materials, of different quality and size. Recently, many different masks have appeared on the market, all at different prices. Skin problems are usually associated with poor air permeability, friction and pressure on the skin. Personal protective equipment must adhere to the skin of the face and is often used for a long time, which results in an increased risk of abrasions and burns. While breathing, we generate steam and the skin evaporates due to the high ambient temperature, which may soften it and reduce the resistance of the stratum corneum, external pressure and shear forces (4).

To increase our protection, we wear disposable gloves. Usually they are made of rubber, plastic (4). As a result, they are waterproof but also poorly breathable. A moist and hot environment is created inside the gloves, favoring the formation of fungus and mycosis on the hands. However, before putting on gloves, it is recommended that you wash your hands hygienically. The use of chemical and biological disinfectants significantly damages the skin barrier. It is now the main cause of dry, itchy and inflamed hands. One study found that $52 \%$ of healthcare professionals with hand eczema wash their hands more than 10 times a day (5). Long-term use of disinfectants also affects the microbiota and changes the immune microenvironment on the skin surface, causing conditions such as eczema, fungal infection, bacterial infection, and allergic dermatitis (6).

Li et al. analyzed the negative health effects of wearing masks, googles and respirators by medical personnel. They described: allergies, excessive skin hydration, local mechanical injuries, and even secondary infections (7).

Atay et al. conducted a study among nurses working in a hospital in Turkey taking care of patients with COVID-19. The main complaints reported due to wearing PPE were: sweating when wearing a surgical $(50.9 \%)$ or N95 (64.2\%) mask, dry hands from wearing gloves (73.9\%), perspiration when wearing overalls/gowns $(84.1 \%)$, and vision problems when wearing goggles/face shields $(47.9 \%)$. They have found a significant relationship between $>4$ hours length of PPE use and the occurrence of: redness of the cheeks, dry mouth, redness of 
the nose bridge, and redness of the ears for N95 masks; dryness of the mouth when wearing surgical masks; skin dryness, sweating, and redness from wearing gloves; headaches from wearing goggles/face shields; and sweating when wearing overalls or a gown (8).

Zhang et al. noticed that negative skin reactions after PPE use reduce enthusiasm for work in medical personnel (9).

In many countries nursing and medical students are called to help with providing care for patients with COVID-19 due to medical personnel shortages worldwide. Therefore it is important that they knew the risks connected with wearing PPE and methods of prevention.

\section{Conclusions}

Wearing masks by students of Medical University of Lublin increases skin problems like acne and reduces the amount of makeup applied. Due to wearing gloves students focus more on moisturizing the skin.

\section{References}

1. Europejskie Centrum ds. Zapobiegania i Kontroli Chorób. Wytyczne dotyczące noszenia i zdejmowania środków ochrony indywidualnej $\mathrm{w}$ placówkach opieki zdrowotnej $\mathrm{w}$ trakcie opieki nad pacjentami chorymi lub podejrzewanymi o zachorowanie na COVID-19. Sztokholm: ECDC; 2020.

2. World Health Organization Wytyczne WHO dotyczące higieny rąk w opiece zdrowotnej - podsumowanie.2009.

3. https://polish.mercola.com/sites/articles/archive/2020/09/04/brak-bezposrednichdowodow-na-zapobieganie-infekcji-przez-noszenie-maseczek.aspx cited on November11,2020.

4. https://www.ncbi.nlm.nih.gov/pmc/articles/PMC7147274/?fbclid=IwAR112K8AyMx MH8L9g1ATVFluW7Gs0Wrz-zwUif0oKmnR2ZfqmMJu2axelhg cited on November11,2020.

5. Ibler KS, Jemec GB, Agner T. Ekspozycje związane z egzemą dłoni: badanie pracowników służby zdrowia . Kontaktowe zapalenie skóry 2012; 66 (5) : 247-253.

6. Rosenthal M, Goldberg D, Aiello A et al. Mikrobiota skóry: struktura społeczności drobnoustrojów i jej potencjalny związek ze zdrowiem i chorobami . Infect Genet Evol 2011; 11 (5) : 839-848.

7. Li C, Shen J, Ju Y, Huang X, Huang L, Zeng K. [Management and prevention of common skin problems during epidemic prevention and control of COVID-19]. Nan Fang Yi Ke Da Xue Xue Bao. 2020 Feb 29;40(2):168-170. Chinese. doi: 10.12122/j.issn.1673-4254.2020.02.05. PMID: 32376531; PMCID: PMC7086135.

8. Atay S, Cura ŞÜ. Problems Encountered by Nurses Due to the Use of Personal Protective Equipment During the Coronavirus Pandemic: Results of a Survey. Wound Manag Prev. 2020 Oct;66(10):12-16. PMID: 33048827.

9. Zhang B, Zhai R, Ma L. 2019 novel coronavirus disease epidemic: skin protection for healthcare workers must not be ignored. J Eur Acad Dermatol Venereol. 2020 May 2:10.1111/jdv.16573. doi: 10.1111/jdv.16573. Epub ahead of print. PMID: 32358808; PMCID: PMC7267421. 